\title{
Imbalance of Calcium, Magnesium, and Phosphorus in Bone and Other Tissues of Rats Induced by Low Protein and Calcium Deficiency
}

\author{
Takahisa TAKedA, Mieko Kimura, and Yoshinori ItokawA \\ Department of Hygiene, Faculty of Medicine, \\ Kyoto University, Kyoto 606-01, Japan
}

(Received February 12, 1993)

\begin{abstract}
Summary Female Wistar rats were separated into 9 groups, and 9 different synthetic diets (each diet contains different level of protein and calcium) were given to each group. After 5 weeks of these dietary regimens, all rats were sacrificed and calcium, magnesium, and phosphorus levels in plasma and various tissues were determined. In calciumdeficient groups, calcium, magnesium, and phosphorus level in bone decreased, plasma calcium level decreased and there was a tendency that magnesium levels in brain and liver and phosphorus level in brain increased. When comparison was made among the calcium-deficient groups, calcium, magnesium, and phosphorus levels in bone were higher in low protein/calcium-deficient group than higher protein/calciumdeficient groups. It is probable that protein deficiency inhibits calcium depletion and consequently the influence of calcium deficiency is less significant in the condition of deficiency in both protein and calcium.

Key Words protein, calcium, magnesium, phosphorus, bone minerals
\end{abstract}

Calcium is an especially important nutrient for maintenance and growth of bone. However, National Nutritional Survey of Japan revealed that the average calcium intake for Japanese is below the recommended dietary allowance and it is a major nutritional problem that patients with osteoporosis are increasing among the aged people in Japan.

Recently, we conducted nutritional survey studies in aged patients at an institution for aged people and found that the intakes of protein and calcium are insufficient for these people (1). As many reports revealed that dietary protein level influences nutritional status of calcium (2-8) and calcium deficiency induces imbalance of other minerals (9-12), we conducted this study to clarify the effect of dietary protein levels on calcium metabolism in relation to influence on metabolism of other minerals. 


\section{MATERIALS AND METHODS}

Three-week-old female Wistar rats were separated into 9 groups (1)-(9) of 78 rats each and 9 different synthetic diets were given ad libitum to these groups. The composition of synthetic diet is shown in Table 1. After 5 weeks of these dietary regimens, rats were anesthetized with sodium pentobarbital and blood was taken from the abdominal aorta until they died by loss of blood. The brain (whole brain), liver, muscle (musculus rectus femoris), and bone (tibia) were then removed. The wet tissue weight was measured. These tissues were wet digested with nitric/perchloric acid mixture in a borosilicate test tube placed in a hot block bath (Model TPB-62, Advantec Toyo Kaisha, Ltd., Tokyo, Japan) at $85^{\circ} \mathrm{C}$ for $24 \mathrm{~h}$ and then heated at $100^{\circ} \mathrm{C}$ for $5 \mathrm{~h}$. Calcium, magnesium, and phosphorus (total phosphorus) were determined using plasma emission spectrometer ICPS-1000 II (Shimadzu Co., Kyoto, Japan).

The data were expressed as $\mathbf{M} \pm \mathbf{S E}$. Statistical significance was calculated by Bonferroni's multiple regression analysis. Statistical treatment was performed by SAS's GLM procedure at the data processing center of Kyoto University.

\section{RESULTS}

Growth curves are shown in Fig. 1. Growth was retarded significantly $(p<$ 0.05 ) in low protein groups (groups (1), (4), (7)) as compared to suboptimal protein (15\% protein) and optimal protein (20\% protein) groups. However, no significant change was observed between suboptimal and optimal protein groups. Difference in calcium intakes did not give a significant change in growth in each protein group.

The calcium concentrations in plasma, brain, liver, and muscles are shown in Table 2. Calcium concentrations in plasma were decreased in calcium-deficient groups (groups (1)-(3)) as compared to control group (group (9)). In low protein groups (groups (1), (4), (7), plasma calcium levels were lower as compared to control group (group (9). Calcium level in plasma increased significantly in suboptimal calcium (a half amount of control in the diet) and normal protein group (group (6)) as compared to control group (group (9)). In other tissues, changes in calcium concentration showed no marked trend, although calcium concentration of brain was increased significantly in low protein and suboptimal calcium group (group (4)) as compared to control group (group (9)).

Table 3 shows magnesium concentrations in plasma, brain, liver, and muscle. There is a tendency that plasma magnesium concentrations increased in calciumdeficient groups (groups (1)-(3)). However, significant difference was not observed. Brain magnesium concentrations were increased significantly in calcium-deficient low protein and suboptimal protein groups (groups (1), (2) and liver magnesium concentrations increased in calcium-deficient and suboptimal and optimal protein groups (groups (2), (3)) as compared to control group (group (9)). 


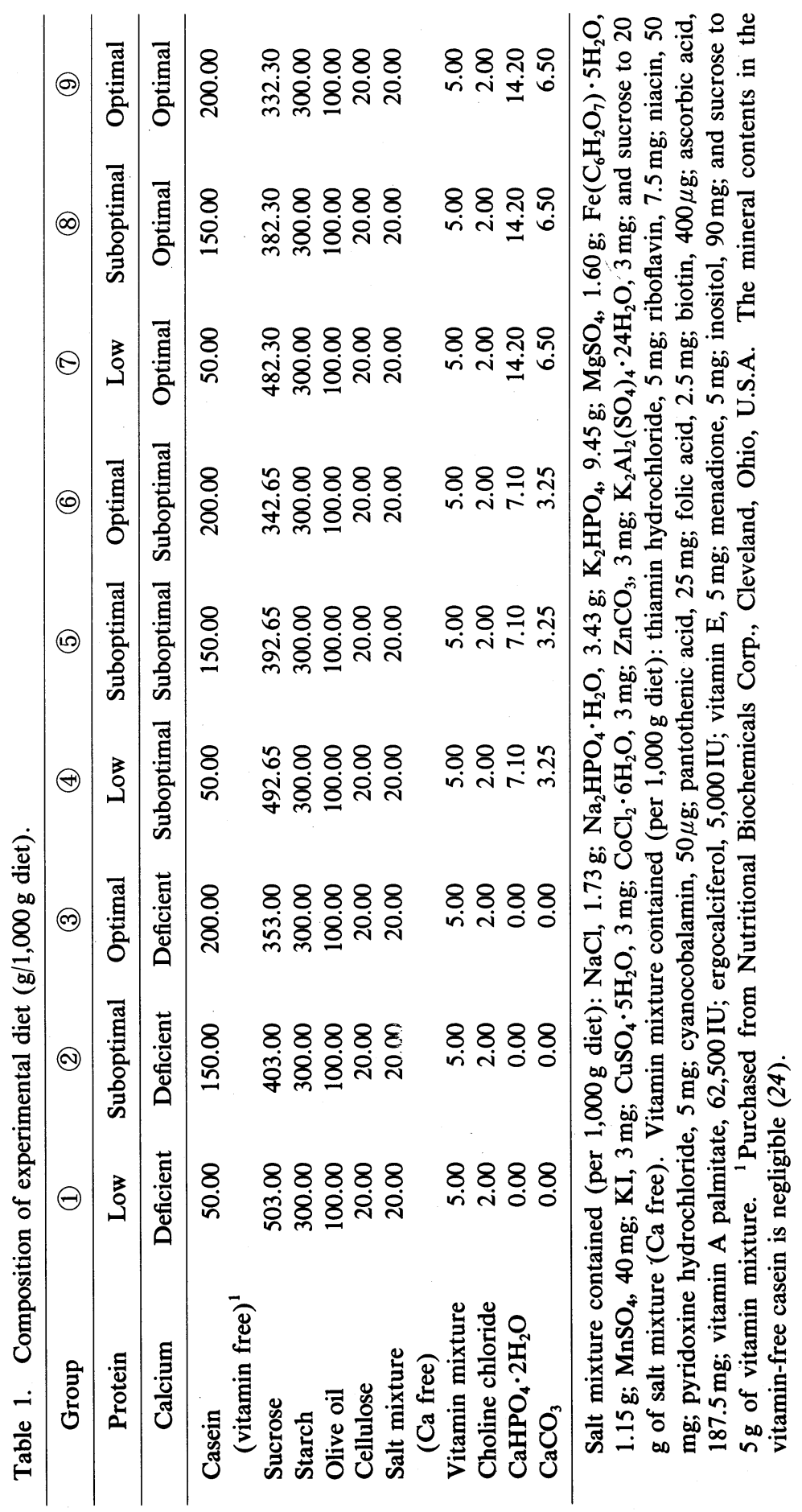




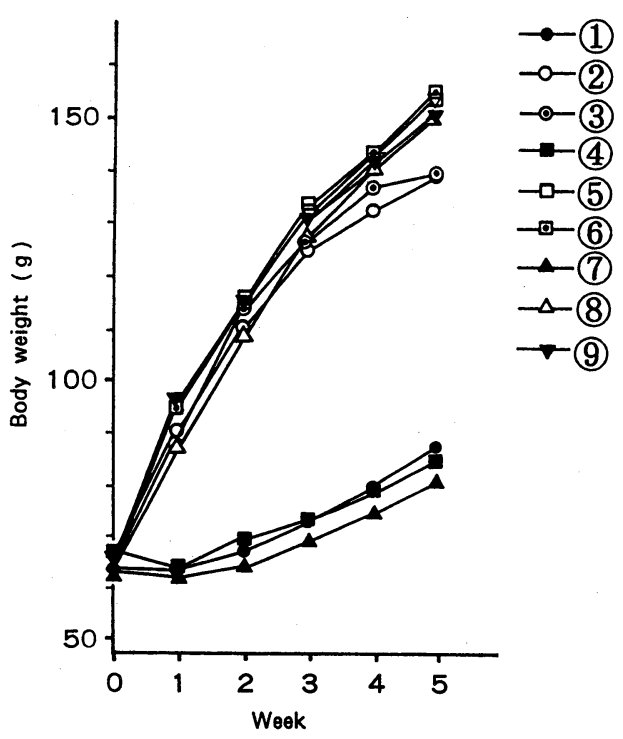

Fig. 1. Growth curves.

Table 2. Calcium concentration in plasma, brain, liver, and muscle.

\begin{tabular}{cccccccc}
\hline & \multirow{2}{*}{$\begin{array}{c}\text { No. } \\
\text { Group }\end{array}$} & \multicolumn{2}{c}{ Diet } & & & & \\
& rats & $\begin{array}{c}\text { Protein } \\
(\%)\end{array}$ & $\begin{array}{c}\text { Calcium } \\
(\mathrm{mg} / \mathrm{kg})\end{array}$ & $\begin{array}{c}\text { Plasma } \\
(\mu \mathrm{g} / \mathrm{ml})\end{array}$ & $\begin{array}{c}\text { Brain } \\
(\mu \mathrm{g} / \mathrm{g})\end{array}$ & $\begin{array}{c}\text { Liver } \\
(\mu \mathrm{g} / \mathrm{g})\end{array}$ & $\begin{array}{c}\text { Muscle } \\
(\mu \mathrm{g} / \mathrm{g})\end{array}$ \\
\hline (1) & 8 & 5 & 0 & $95.5 \pm 2.0^{*}$ & $49.5 \pm 6.1$ & $34.4 \pm 5.8$ & $55.8 \pm 7.8$ \\
$(2)$ & 7 & 15 & 0 & $95.2 \pm 4.1^{*}$ & $45.9 \pm 3.3$ & $36.8 \pm 2.2$ & $52.0 \pm 3.6$ \\
$(3)$ & 8 & 20 & 0 & $95.2 \pm 4.5^{*}$ & $47.7 \pm 7.6$ & $33.3 \pm 3.2$ & $52.3 \pm 3.8$ \\
$(4)$ & 8 & 5 & 250 & $95.4 \pm 5.7^{*}$ & $64.1 \pm 21.7^{*}$ & $33.3 \pm 3.0$ & $52.1 \pm 1.4$ \\
$(5)$ & 7 & 15 & 250 & $104.8 \pm 2.5$ & $61.1 \pm 28.4$ & $37.7 \pm 2.8$ & $56.7 \pm 8.1$ \\
$(6)$ & 6 & 20 & 250 & $116.6 \pm 22.8^{*}$ & $63.1 \pm 38.0$ & $36.6 \pm 3.0$ & $51.7 \pm 2.3$ \\
$(7)$ & 7 & 5 & 500 & $98.1 \pm 2.5^{*}$ & $55.5 \pm 19.4$ & $32.2 \pm 2.4$ & $56.5 \pm 6.9$ \\
$(8)$ & 6 & 15 & 500 & $105.9 \pm 2.9$ & $52.7 \pm 15.2$ & $34.7 \pm 1.4$ & $53.9 \pm 4.5$ \\
(9) & 6 & 20 & 500 & $105.5 \pm 6.0$ & $46.7 \pm 7.8$ & $40.1 \pm 2.2$ & $55.9 \pm 2.5$ \\
\hline
\end{tabular}

$\mathbf{M} \pm$ SD. ${ }^{*}$ Significant difference $(p<0.05)$ as compared to group (9) (control group).

Concentrations of phosphorus in plasma, brain, liver, and muscle are shown in Table 4. Phosphorus levels in brain increased in calcium-deficient groups (groups (1)-(3)) and low protein groups (groups (1), (4), (7) as compared to control group (group (9)).

Figures 2-4 show the concentrations of calcium, magnesium, and phosphorus in bone of these individual rats. In bone, calcium levels decreased significantly in calcium-deficient groups (groups (1)-(3)). When comparison was made among the calcium-deficient groups, calcium levels in bone decreased significantly in sub- 
Table 3. Magnesium concentration in plasma, brain, liver, and muscle.

\begin{tabular}{|c|c|c|c|c|c|c|c|}
\hline \multirow[b]{2}{*}{ Group } & \multirow{2}{*}{$\begin{array}{l}\text { No. } \\
\text { of } \\
\text { rats }\end{array}$} & \multicolumn{2}{|c|}{ Diet } & \multirow{2}{*}{$\begin{array}{l}\text { Plasma } \\
(\mu \mathrm{g} / \mathrm{ml})\end{array}$} & \multirow[b]{2}{*}{$\begin{array}{l}\text { Brain } \\
(\mu \mathrm{g} / \mathrm{g})\end{array}$} & \multirow[b]{2}{*}{$\begin{array}{l}\text { Liver } \\
(\mu \mathrm{g} / \mathrm{g})\end{array}$} & \multirow[b]{2}{*}{$\begin{array}{l}\text { Muscle } \\
(\mu \mathrm{g} / \mathrm{g})\end{array}$} \\
\hline & & $\begin{array}{c}\text { Protein } \\
(\%)\end{array}$ & $\begin{array}{l}\text { Calcium } \\
(\mathrm{mg} / \mathrm{kg})\end{array}$ & & & & \\
\hline (1) & 8 & 5 & 0 & $13.4 \pm 1.5$ & $160.3 \pm 8.2^{*}$ & $238.2 \pm 7.4$ & $302.5 \pm 7.9$ \\
\hline (2) & 7 & 15 & 0 & $14.3 \pm 2.2$ & $158.0 \pm 1.4^{*}$ & $241.5 \pm 7.2^{*}$ & $309.0 \pm 13.2$ \\
\hline (3) & 8 & 20 & 0 & $16.5 \pm 1.9$ & $155.9 \pm 2.6$ & $242.4 \pm 5.0^{*}$ & $311.5 \pm 8.3$ \\
\hline (4) & 8 & 5 & 250 & $10.9 \pm 2.1$ & $159.7 \pm 8.5^{*}$ & $231.3 \pm 6.0$ & $304.5 \pm 6.4$ \\
\hline (5) & 7 & 15 & 250 & $13.6 \pm 1.1$ & $153.7 \pm 3.4$ & $238.1 \pm 5.4$ & $307.3 \pm 18.1$ \\
\hline (6) & 6 & 20 & 250 & $12.4 \pm 1.8$ & $153.6 \pm 3.0$ & $231.0 \pm 3.7$ & $304.5 \pm 12.6$ \\
\hline (7) & 7 & 5 & 500 & $10.5 \pm 1.4$ & $154.1 \pm 3.5$ & $231.7 \pm 8.9$ & $297.8 \pm 10.1$ \\
\hline (8) & 6 & 15 & 500 & $11.6 \pm 1.9$ & $152.2 \pm 2.0$ & $232.6 \pm 10.7$ & $303.8 \pm 11.0$ \\
\hline (9) & 6 & 20 & 500 & $11.4 \pm 2.0$ & $152.4 \pm 1.8$ & $229.9 \pm 1.8$ & $303.6 \pm 10.3$ \\
\hline
\end{tabular}

$\mathbf{M} \pm$ SD. ${ }^{*}$ Significant difference $(p<0.05)$ as compared to group (9) (control group).

Table 4. Phosphorus concentration in plasma, brain, liver, and muscle.

\begin{tabular}{|c|c|c|c|c|c|c|c|}
\hline \multirow[b]{2}{*}{ Group } & \multirow{2}{*}{$\begin{array}{l}\text { No. } \\
\text { of } \\
\text { rats }\end{array}$} & \multicolumn{2}{|c|}{ Diet } & \multirow{2}{*}{$\begin{array}{l}\text { Plasma } \\
(\mu \mathrm{g} / \mathrm{ml})\end{array}$} & \multirow{2}{*}{$\begin{array}{l}\text { Brain } \\
(\mu \mathrm{g} / \mathrm{g})\end{array}$} & \multirow{2}{*}{$\begin{array}{l}\text { Liver } \\
(\mu \mathrm{g} / \mathrm{g})\end{array}$} & \multirow{2}{*}{$\begin{array}{l}\text { Muscle } \\
(\mu \mathrm{g} / \mathrm{g})\end{array}$} \\
\hline & & $\begin{array}{l}\text { Protein } \\
(\%)\end{array}$ & $\begin{array}{l}\text { Calcium } \\
(\mathrm{mg} / \mathrm{kg})\end{array}$ & & & & \\
\hline (1) & 8 & 5 & 0 & $119.1 \pm 13.7$ & $3,443 \pm 206^{*}$ & $3,504 \pm 141$ & $2,593 \pm 66$ \\
\hline (2) & 7 & 15 & 0 & $133.6 \pm 9.1$ & $3,333 \pm 57^{*}$ & $3,766 \pm 155$ & $2,590 \pm 131$ \\
\hline (3) & 8 & 20 & 0 & $130.6 \pm 5.4$ & $3,324 \pm 91^{*}$ & $3,724 \pm 60$ & $2,560 \pm 87$ \\
\hline (4) & 8 & 5 & 250 & $128.3 \pm 19.5$ & $3,427 \pm 231^{*}$ & $3,463 \pm 72$ & $2,638 \pm 100$ \\
\hline (5) & 7 & 15 & 250 & $138.8 \pm 11.8$ & $3,289 \pm 33$ & $3,726 \pm 183$ & $2,612 \pm 154$ \\
\hline (6) & 6 & 20 & 250 & $132.8 \pm 8.1$ & $3,265 \pm 56$ & $3,493 \pm 62$ & $2,586 \pm 96$ \\
\hline (7) & 7 & 5 & 500 & $124.8 \pm 12.5$ & $3,305 \pm 52$ & $3,547 \pm 180$ & $2,660 \pm 91$ \\
\hline (8) & 6 & 15 & 500 & $136.9 \pm 9.2$ & $3,157 \pm 38$ & $3,572 \pm 117$ & $2,616 \pm 107$ \\
\hline (9) & 6 & 20 & 500 & $129.2 \pm 8.9$ & $3,122 \pm 44$ & $3,632 \pm 214$ & $2,568 \pm 95$ \\
\hline
\end{tabular}

$\mathbf{M} \pm$ SD. ${ }^{*}$ Significant difference $(p<0.05)$ as compared to group (9) (control group).

optimal and optimal protein groups (groups (2), (3)) as compared to low protein calcium deficient group (group (1)). Similar relationships were observed also in concentrations of magnesium and phosphorus in bone.

\section{DISCUSSION}

Typical changes in minerals of calcium-deficient rats were characterized by hypocalcemia and decrease in calcium levels in bone $(10,11)$. In addition to these typical changes, the present report revealed that magnesium and phosphorus levels in bone decreased and there were tendencies that magnesium levels in brain and liver and phosphorus level in brain increased. Approximately $99 \%$ of calcium, $60 \%$ 


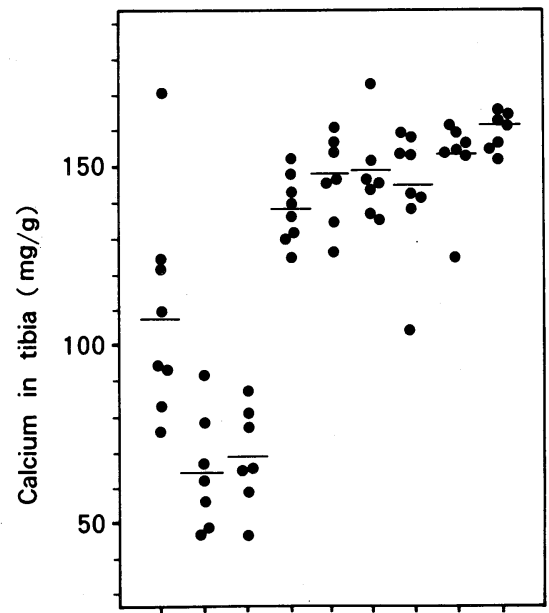

(1) (2) (3) (4) (5) (6) (7) (8) (9)

Fig. 2

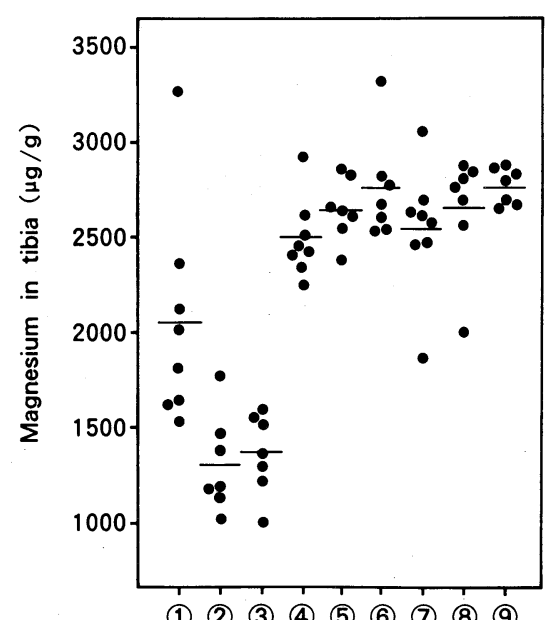

(1) (2) (3) (4) (5) (6) (7) (8) (9)

Fig. 3

Fig. 2. Calcium concentration in tibia of individual rats. Mean values of groups (1)-(3) are significantly different $(p<0.05)$ from mean value of group (9). Mean values of groups (2), (3) are significantly different $(p<0.05)$ from mean value of group (1).

Fig. 3. Magnesium concentrations in tibia of individual rats. Mean values of groups (1)-(3) are significantly different $(p<0.05)$ from mean value of group (9). Mean values of groups (2), (3) are significantly different $(p<0.05)$ from mean value of group (1).

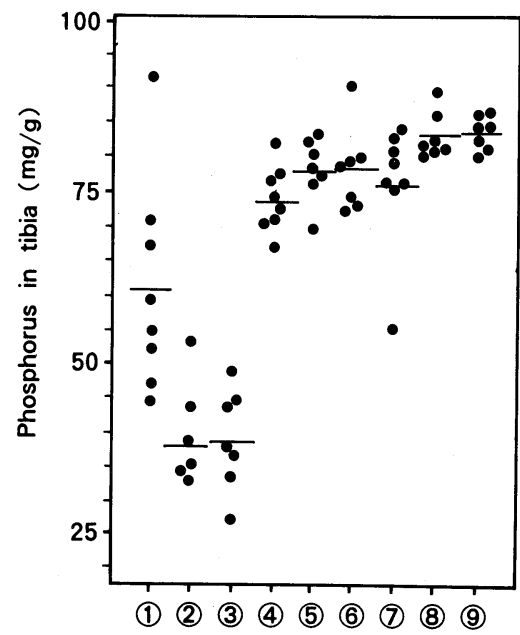

Fig. 4. Phosphorus concentrations in tibia of individual rats. Mean values of groups (1)-(3) are significantly different $(p<0.05)$ from mean value of group (9). Mean values of groups (2), (3) are significantly different $(p<0.05)$ from mean value of group (1). 
of the magnesium, and $80 \%$ of phosphorus in the body are in the bones and teeth, and the store of these minerals in these hard tissues is utilized easily in the body (13, 14). It is therefore assumed that these minerals released from the bones to other tissues thereby promoting homeostatic adaptation.

Of note in the present study is the discovery of mineral changes in bone in protein-deficient calcium-deficient rats. Decreased calcium, magnesium, and phosphorus levels in bone in calcium-deficient rats were alleviated significantly when the animals were also deficient in protein. Excessive intakes of protein are known to increase the urinary caclium excretion (3-7) and it can be observed that high protein diet caused a negative net balance of calcium even when calcium intake was sufficient (15-17). Furthermore, it is reported that a diet with excessive meat (18) and calcium deficiency is a factor in causing osteoprosis (19-22). It is probable that substantial body calcium is lost in calcium deficiency when protein intake is high, but calcium equilibrium can be achieved when protein intake is low even if calcium intake is low. The present experiment reconfirmed this fact and in addition, it was clarified that not only calcium but also magnesium and phosphorus could be lost from bones in a similar manner.

Although the exact mechanism of the sparing effect of low protein diet on calcium, magnesium, and phosphorus in bones is unclear, it is assumed that food habits such as consumption of high protein and low calcium could promote the decrease in calcium, magnesium, and phosphorus in bones. Thus, there is a possibility that such an imbalance of calcium and protein intake could have a relation to the development of osteoprotic changes.

Bone and teeth contain certain amounts of magnesium. It may play an important role in the initial formation of apatite and have a significant effect on their physicochemical properties (23). Attention should be paid to magnesium metabolism as well as metabolisms of calcium and phosphorus as the etiology of bone disease.

Another finding of this study is hypocalcemia found in low protein rats. The reason for this finding is not clear yet; protein deficiency may influence intestinal absorption, transport, or homeostatic adaptation mechanisms of calcium.

The authors wish to express gratitude to Drs. Katsuhiko Yokoi and Shinichi Nakagawa in our department for their valuable discussions. Thanks are also due to Miss Tomoko Yamaguchi for technical assistance.

\section{REFERENCES}

1) Takeda, T., Kanehira, K., Nagai, K., Kimura, M., and Itokawa, Y. (1990): Survey of food intake in an intermediate facility for the aged. Jpn. J. Hyg., 45, 242.

2) LeRoith, D., and Pimstone, B. L. (1973): Bone metabolism and composition in the protein-deprived rat. Clin. Sci., 44, 305-319.

3) Margen, S., Chu, J.-Y., Kaufmann, N. A., and Calloway, D. H. (1974): Studies in 
calcium metabolism, I. The calcium effect of dietary protein. Am. J. Clin. Nutr., 27, 584-589.

4) Chu, J.-Y., Margen, S., and Costa, F. M. (1975): Studies in calcium metabolism. II. Effects of low calcium and variable protein intake on human calcium metabolism. Am. J. Clin. Nutr., 28, 1028-1035.

5) Allen, L. H., Oddoye, E. A., and Margen, S. (1979): Protein-induced hypercalciuria: A long term study. Am. J. Clin. Nutr., 32, 741-749.

6) Schuette, S. A., Zemel, M. B., and Linkswiller, H. M. (1980): Studies on the mechanism of protein-induced hypercalcemia in older men and women. J. Nutr., 110, 305-315.

7) Azami, S.,and Hiratsuka, S. (1982): Effect of dietary protein quantity and its quality on urinary calcium excretion in female rat. Seitoku Eiyou Tankidaigaku Kiyo, 13, 2125.

8) Orwoll, E., Ware, M., Stribrska, L., Bikle, D., Sanchez, T., Andon, M., and Li, H. (1992): Effects of dietary protein deficiency on mineral metabolism and bone mineral density. Am. J. Clin. Nutr., 56, 314-319.

9) Ahmed, S. M, Kimura, M., Yamakawa, T., and Itokawa, Y. (1986): Changes of magnesium, calcium and iron metabolism in rats fed low protein-low energy diet. $J$. Jpn. Soc. Mg Res., 5, 15-23.

10) Itokawa, Y., Tanaka, C., and Fujiwara, M. (1974): Changes in body temperature and blood pressure in rats with calcium and magnesium deficiency. J. Appl. Physiol., 37, 835-839.

11) Iwabuchi, A., Notani, C., Tsutsui, Y., Kimura, M., and Itokawa, Y. (1985): Changes in tissue mineral lelvels in calcium deficient rats. J. Jpn. Soc. Mg Res., 4, 45-51.

12) Kimura, M., Iwabuchi, A., Sekine, K., and Itokawa, Y. (1985): Mineral unbalance induced by calcium deficiency. Response of calcium readministration. J. Trace Nutr. Res., 2, 89-98.

13) Johnson, N. E., Alcantara, E. N., and Linkswiler, H. (1970): Effect of level of protein intake on urinary and fecal calcium and calcium retention of young adult males. $J$. Nutr., 100, 1425-1430.

14.) Gitelman, H. J., and Welt, L. G. (1969): Magenesium deficiency. Annu. Rev. Med., 20, 233-242.

15) Bogert, L., Briggs, G. M., and Calloway, D. H. (1966): Nutrition and Physical Fitness, W. B. Saunders Co., Philadelphia and London, pp.. 148-170.

16) Anand, C. R., and Linkswiler, H. M. (1974): Effect of protein intake on calcium balance of young men given $500 \mathrm{mg}$ calcium daily. J. Nutr., 104, 695-700.

17) Linkswiler, H. M., Joyce, C. L., and Anand, C. R. (1974): Calcium retention of young adult males as affected by level of protein and of calcium intake. Trans. N. Y. Acad. Sci. Ser. II, 36, 333-340.

18) Sherman, H. C. (1920): Calcium requirement of maintenace in man. J. Biol. Chem., 44, 21-27.

19) Riggs, L., and Melton, L. J. (1983): Evidence for two distinct syndromes of involutional osteoporosis. Am. J. Med., 75, 899-901.

20) Parfitt, A. M. (1983): Dietary risk facotrs for age-related bone loss and fractures. Lancet, ii, 1181-1185.

21) Hegsted, D. M. (1986): Calcium and osteoprosis. J. Nutr., 116, 2316-2319. 
22) Riggs, B. L., Wahner, H. W., Melton, L. J., Richeison, L. S., Judd, H. L., and O'Fallon, W. M. (1987): Dietary calcium intake and of bone loss in women. J. Clin. Invest., 80, 979-982.

23) Okazaki, M. (1989): The role of magnesium in synthetic apatites, in Magnesium in Health and Disease, ed. by Itokawa, Y., and Durlach, J. John Libbey Inc., London, Paris, pp. 21-26.

24) Zhu, Z., Kimura, M., and Itokawa, Y. (1993): Mineral status in selenium-deficient rats compared to selenium-sufficient rats fed vitamin-free casein-based or torula yeast-based diet. Biol. Trace Elem. Res., 37, 219-231. 